\title{
Gamification and Technology-Based Learning: Uncovering the Potential of Using Games in Language Teaching and Learning
}

\author{
Fahad H. Abdeen \\ Dept. of Curiculum \& Instrction, University of Arakansas \\ E-mail: fabdeen77@gmail.com
}

Waheeb S. Albiladi

Department of Curriculum \& Instruction

E-mail: walbilad@gmail.com

Received: Feb. 23, 2021

Accepted: April 29, $2021 \quad$ Published: May 1, 2021

doi:10.5296/jse.v11i2.18339

URL: https://doi.org/10.5296/jse.v11i2.18339

\begin{abstract}
The use of games in education has received much attention from educators who perceive games as a motivational tool that can enhance their teaching and learning practice. Gamification in education is a relatively new field that promotes the use of games for educational purposes. Gamification or game-bases teaching is a growing trend among educational institutions, which use it to promote training, develop problem-solving skills in learners, and enhance the learning experience. The present paper aims to revisit the literature on the use of gamification in educational settings. Specifically, the paper discusses the use of gamification for teaching and learning English in the ESL/EFL context. Games have been used effectively with language learners to develop their skills in speaking, listening, writing, reading, and grammar.
\end{abstract}

Keywords: Gamification, game-based learning, English teaching, educational Technology 


\section{Introduction}

\subsection{Introduce the Problem}

Gamification is a relatively new concept related to several fields, including but not limited to business, training, social policy, and education. Kapp (2012) believes that gamification is a growing trend among educational institutions, who use it to promote training, develop problemsolving skills in learners, and enhance the learning experience. Recently, the term has been used by researchers to promote the use of games in educational settings. Lavoué, Monterrat, Desmarais, and George (2018) write that gamification is different from learning games, which refers to using games for teaching and learning. In contrast, gamification refers to using game design elements in learning activities.

Similarly, Kapp (2012) defines gamification as "using game-based mechanics, aesthetics and game thinking to engage people, motivate action, promote learning, and solve problems" ( $\mathrm{p}$. 10). Similarly, Kirillov, Vinichenko, Melnichuk, Melnichuk, and Vinogradova (2016) point out that gamification means applying game mechanics, elements, and principles in non-gaming contexts such as education.

The use of games in education has been emphasized by researchers who view games as motivational tools. Dicheva, Dichev, Agre, and Angelova (2015) note that using games in learning is a promising way to support and reinforce knowledge, as well as develop other significant skills such as problem-solving, collaboration, and communication. Research (by Kapp, 2013: Kingsley \& Grabner - Hagen, 2015; Klopfer, 2008; Tan et al. 2019) has identified several benefits of using gamification as an instructional and teaching tool. Kingsley and Grabner - Hagen (2015) point out that gamification' s highly engaging learning environment provides opportunities to combine literacy, classroom instruction, and 21st-century skills development. Similarly, Ott and Tavella (2009) maintain that gamification strategies help increase student motivation and engagement in the learning process. That is because gamebased learning makes learning more enjoyable, attractive and, more importantly, effective. Kapp (2013) also mentions that using gamification or game-based learning has benefits such as improved classroom interaction and engagement, more opportunities for deep thinking, and increased classroom authenticity. Gamification helps enhance and improve the learning environment by increasing student involvement and participation in the learning process (Kirillov et al. 2016). Klopfer (2008) emphasizes the integration of games in the teaching practices by stating:

Mobile games excel at connecting to existing classroom ecologies, and extending them in powerful new directions. These games fit naturally into the current landscape of teaching and learning in current schools, and also can connect school, game play, and the real world (p. 221).

\section{Review of the Current Literature}

Huang and Soman (2013) note that gamification is a process that involves several steps to ensure effective integration of games in education and allows teachers to conduct effective game-based teaching practices. The first step is to understand both the target audience and the 
context. This includes knowing the target audience and its diverse characteristics (e.g., age group, learning abilities, skills) and the settings in which games might be used. The second step is to define and address the learning objectives. Teachers should know what learning objectives students must accomplish by the end of the teaching period. Setting general and specific goals for teaching and learning is essential to the successful application of gamification. The third step is to structure the teaching and learning experiences by breaking the teaching process down into stages and sequences. This helps teachers judge the learning objectives and the overall teaching and learning process.

The fourth step involves identifying necessary resources. Teachers need to know what resources and materials they need to use gamification in class. The final step is to apply the various gamification elements. According to Huang and Soman (2013), gamification is a process with elements that can be applied to teaching practice. These elements include selfassessments, which refer to the ways teachers encourage students to compete with themselves (such as points, time restrictions, or different levels). Social elements also determine students' interaction and cooperation with other students.

\section{Studies on Gamification and Game-based Learning in the ESL/EFL Context}

Games have been effectively applied to teaching English in the second-language or foreignlanguage context. Researchers have examined the use of games for teaching English subjects including reading, writing, speaking, listening, grammar and vocabulary. Research has indicated that the use of games in teaching and learning English has many academic and instructional benefits such as increased student motivation, an enhanced learning environment, and more authentic learning experiences.

The review of the current literature indicates that games have been used mostly to teach grammar and vocabulary. Research also indicates that of the educational games can be used to teach oral skills (speaking and listening) or written skills (reading and writing) in the ESL/EFL context. Accordingly, the following table includes an overview of the findings related to the use of games in ESL/EFL context. Table 1 provides an overview of the research findings related to the use of games in ESL/EFL context: 
Table 1. Overview of the findings related to the use of games in ESL/EFL context

\begin{tabular}{ll}
\hline \multicolumn{1}{c}{ Findings } & \multicolumn{1}{c}{ Research Studies Reviewed } \\
\hline Game-based learning as means to develop the & Cam \& Tran (2017); Gamlo (2019); \\
grammar of English language learners & Jalali \& Dousti (2012); Yolageldili \& \\
& $\begin{array}{l}\text { Arikan (2011); Yukselturk, Altiok } \\
\text { \&Baser (2018) }\end{array}$
\end{tabular}

Game-based learning as means to develop the vocabulary of English language learners

Game-based learning as means to develop the listening and speaking of English language learners

Game-based learning as means to develop the reading and writing of English language learners
Franciosi (2017); Gamlo (2019); Jalali \& Dousti (2012); McGregor, Marshall, Julian, \& Oleson (2019)

Gamlo (2019); Anderson, Reynolds, Yeh, \& Huang (2008)

Lin, Hwang, Fu \& Chen (2018)

For instance, Cam and Tran (2017) conducted a mixed research method to investigate the use of games to teach English grammar in a technology university in Vietnam. The study aimed to reveal how grammar can help language learners acquire grammar and their attitude towards using games to learn grammar. The participants included 25 English language learners attending a grammar course. Questionnaires, observation, and semi-structured interviews were used to collect the data. These research methods were employed to examine the students' attitudes, reactions, and opinions regarding the use of games to learn grammar. Results from both the quantitative and qualitative approaches indicated that the participants demonstrated a positive attitude towards using games as learning tools. The researchers stated that the use of games helped create an enjoyable and motivating learning environment. The use of games reduced the stress of learning grammar.

Similarly, in a quasi-experimental study, Jalali and Dousti (2012) examined the use of educational games in teaching English grammar and vocabulary. Specifically, the study investigated the effect of using computer-based games in elementary English language learners' grammar and vocabulary gains. Fifty-eight female elementary learners aged between 13 and 15 participated in the study. The researchers used pre- and post-tests (with controls) and experimental groups to collect the data. Even though the results showed no significant difference between the experimental and control groups, the level of involvement and the motivation of the experimental groups were noticeable. The researchers concluded that educational games can be used to improve students' attitudes and increase their motivation to learn English grammar and vocabulary.

In similar research study, Yolageldili and Arikan (2011) explored the effectiveness of using educational games to teach English grammar. In particular, the study aimed to explore EFL 
teachers' perceptions and opinions regarding the use of games as tools to teach grammar. The study included 15 EFL teachers working in different primary schools in Turkey. The researchers used a questionnaire to gather the teachers' perceptions and opinions about the role of games in teaching grammar. The results indicated that the majority of the participants believed that games are effective tools for teaching English grammar. The teachers also believed that the use of games provide an opportunity to teach more explicit grammar rules. However, games can be used effectively as language teaching tools because they provide learners with a meaningful and enjoyable context within which they can apply their knowledge of grammar.

Yukselturk, Altiok, and Baser (2018) investigated the effect of game-based learning with Kinetic technology on Turkish EFL students' grammar and communication skills. Sixty-two first-year students who are taking English as a compulsory course were selected randomly. The researchers organized the students in groups of six, and each researcher instructed his/her groups to perform a specific activity-based learning activity, since kinesthetic learning involves learning through physical activity rather than listening to a lecture, reading books, or watching demonstrations. Some of the activities assigned to the groups included the use of models to form letters, words, and sentences; the use of letter tiles to spell and read words; and the use of marker pens to write letters and words on a large beach ball, among other games. Questionnaires and observation were used to measure students' self-efficacy, beliefs, and attitudes toward English. The results of the study revealed that the students were much better able to acquire, understand, and retain what they learned.

Moreover, the students were able to create a connection between language and concepts.

In a more recent study, Lin, Hwang, Fu, and Chen (2018) investigated the use of flipped contextual game-based learning as an approach to improve the English writing performance of EFL business students. In this approach, a story-based learning model (role-play) was used. Students used peer interactions along with more practice (correspondence grammar, writing a business letter) in class. The teacher in this case guided the learning process. Sixty-eight students aged between 18 and 22 participated in this study. The experimental group consisted of 35 students, while the control group had 33 students. A mixed research method (quantitative and qualitative) was used to collect the data. The data were collected through an online learning system where students could complete their online tasks and upload documents. Moreover, the participants completed a survey with open-ended questions to share their feedback on the learning approaches. The result of the study statistically showed that the participants who used the flipped learning approach performed better at writing performance and had fewer writing errors compared with the control group. In addition, the participants said they enjoyed using the learning approach, and that the story-based context platform was easy to use.

In another study, Vahdat and Behbahani (2013) investigated the use of games to teach English as a foreign language in an Iranian intermediate school. The study included 40 intermediate EFL learners who were divided into two groups. The first group (the control group) studied English vocabulary in more traditional ways, whereas the second group (the experimental group) was taught new vocabulary using video games. The two groups were tested to identify the effect of video games on the teaching and learning of new English words. The findings 
suggest that using video games results in better learning of the vocabulary. In other words, video games can be beneficial when used a tool to teach and learn English vocabulary. The author concluded that "Language teachers are advised to use video games in their classrooms, especially for vocabulary building.” (p. 69)

Franciosi (2017) conducted an interesting study to investigate the use of computer game-based learning to not only improve English vocabulary, but also to improve the transferability of learned vocabulary of Japanese students. This study yielded results similar to those of Vahdat and Behbahani (2013). Franciosi's first study had 23 students who used computer game-based lesson (Energy City; the control group had 61 students. Pre- and post-vocabulary tests, along with writing tasks, were used to collect the data. The participants in the experimental group were exposed to the online game Energy City for ten minutes and asked to play the game in groups for 60 minutes. The result of this part of the study statistically revealed that the number of vocabulary list words was higher in the writing task among the participants who used the game-based learning. The second study was conducted in the following academic semester but with different students, to align the use of the targeted vocabulary with students' degree of participation in computer game-based lessons. Data were collected through a writing task, test scores, and a debriefing online report after playing Energy City, which the author considered to be participation in game-based learning. The result of this study revealed that participants are more likely to utilize the keyboard in writing tasks after completing game-based lessons.

In addition, Anderson, Reynolds, Yeh, and Huang (2008) examined the effect of using video games to develop the listening skills of English language learners in Taiwan. The study aimed to determine EFL learners' perceptions and attitudes about using video games to learn English and whether these games could be used to increase their listening comprehension. The study unfolded in two phases. In the first phase, eight EFL learners participated in video game training that aimed to develop their listening skills. In these sessions, the learners were observed and interviewed to explore their perceptions of video games as tools for learning English. In the second phase, the researchers conducted an experiment in which 25 graduate and undergraduate students were divided into two groups. One group received traditional instruction, while the other group learned through video games. The listening comprehension of both groups was assessed in pre- and post-tests. The results of the first phase indicated that students showed a positive attitude toward using video games to improve their language proficiency. In addition, the participants expressed a positive feedback (including fun and enjoyment) about using video games as a learning tool for English.

In a more recent study, McGregor, Marshall, Julian, and Oleson (2019) used a trial of games as learning tools for college students to develop their vocabularies. Participants in this study were 40 undergraduate students who planned to take the GRE exam (Graduate Record Examinations) in the year after the treatment. A single-site, prospective, and randomized trial was used in this study, specifically, immediate and delayed treatment. The training platform was a website (Vocabulary.com) that asks the learner to answer a battery of questions about a word. The website also presents feedback to the players they if give incorrect answers. This game-based website can also provide points and badges to players who reach certain levels. The measurement outcomes in this study were the number of words that were accurately 
defined on Vocabulary.com and the students' test scores on the GRE (verbal section) before and after the treatment. The results of this study indicated a significant relationship between play and mastery. More play time will result in the student learning and mastering new words. Also, although participants who learned more words per minute of play did not earn high scores in the GRE, they scored higher compared with others.

Similarly, Gamlo (2019) examined the use of mobile games to learn whether it might increase motivation to learn English among freshmen EFL students. The study focused on understanding the participants' perceptions of the pedagogical value of a variety of mobile learning applications, most of which are designed to improve grammar, vocabulary, and reading. The mobile game-based applications provide points, badges, and stats for players who complete a task or level. In this study, data were collected via two modified questionnaires (pre and post) that aimed to elicit information about students' motivations and the impact of the applications. The study revealed that students were highly motivated before the intervention. The researcher attributed this to the participants' condition as freshmen students who wanted to achieve the best possible scores so they apply for their desired major. The results also revealed that using mobile applications can help motivate people to learn English. The study also recommended that teachers of second-language students utilize mobile games, based on the finding that they have the potential to foster language learning and increase student motivation. The applications used in this study included Game books: Great Reader, Game to learn English - English Tracker, and Learn English Vocabulary Pop Quiz.

\section{Implications for Future Research}

Research on game-based learning is increasing. Albiladi, Abdeen, and Lincoln, F. (2018) have argued that games and movies are authentic and engaging learning tools in language classrooms. However, there still room for new knowledge about how gamification can change the learning and teaching process. In a recent research study, Sarigoz (2019) indicated that abandonment of digital games as a learning tool was based on gender. This study raises many questions about how gamification can impact how teachers teach and how students learn. For instance, more research could be done to understand the relationship between teachers' demographic profiles and game-based learning among ESL/EFL teachers. This could help to identify limitations related to the nature of the learning tool, students, or teachers. Another idea is to conduct a research study to examine the effect of game-based learning on the learning environment, including how teachers deliver their instruction and how students perceive the learning process.

\section{Conclusion}

This paper aims to revisit the literature on game-based learning in educational settings. This review shows a decrease in the number of studies that focus on the use of game-based learning and teaching of English in ESL/EFL classes. In fact, limited evidence was found to support the idea that games help improve skills such as grammar, writing, vocabulary, and listening in ESL/EFL learners. Additionally, very limited, if any, research was found to reveal how gamebased learning can be used to develop other skills like speaking and reading. The findings of this paper are very important, as they highlight a gap in the literature. This opens up an opportunity for other researchers to explore the potential of using games in the ESL/EFL 
context. Moreover, future research can focus on exploring learning tools that have been used effectively in ESL/EFL teaching and learning. Most of the revised articles talked about motivation as a major benefit of game-based learning. Other benefits should be explored to gain more insight into the potential of using games in ESL/EFL settings

\section{References}

Albiladi, W. S., Abdeen, F. H., \& Lincoln, F. (2018). Learning English through movies: Adult English language learners' perceptions. Theory and Practice in Language Studies, 8(12), 15671574. https://doi.org/10.17507/tpls.0812.01

Anderson, T., Reynolds, B. L., Yeh, X., \& Huang, G. (2008). Video games in the English as a foreign language classroom. Paper presented at the 188-192. https://doi.org/10.1109/DIGITEL.2008.39

Cam, L., \& Tran, T. T. M. (2017). An evaluation of using games in teaching English grammar for first year English-majored students at Dong Nai Technology University. International Journal of Learning, Teaching and Educational Research, 16(7), 55-71.

Dicheva, D., Dichev, C., Agre, G., \& Angelova, G. (2015). Gamification in education: A systematic mapping study. Journal of Educational Technology \& Society, 18(3), 75-88.

Franciosi, S. J. (2017). The effect of computer game-based learning on FL vocabulary transferability. Journal of Educational Technology \& Society, 20(1), 123-133.

Gamlo, N. (2019). The Impact of Mobile Game-Based Language Learning Apps on EFL Learners' Motivation. English Language Teaching, 12(4), 49-56. https://doi.org/10.5539/elt.v12n4p49

Huang, W. H., \& Soman, D. (2013). A Practitioner's Guide to Gamification of Education. Research Reports Series, Behavioural Economics in Action. Toronto, ON: Rotman School of Management, University of Toronto.

Jalali, S., \& Dousti, M. (2012). Vocabulary and grammar gain through computer educational games. GEMA Online ${ }^{\circledR}$ Journal of Language Studies, 12(4), 1077-1088.

Kapp, K. M. (2013). The gamification of learning and instruction fieldbook: Ideas into practice. San Francisco, CA: John Wiley \& Sons.

Kingsley, T. L., \& Grabner-Hagen, M. M. (2015). gamification. Journal of Adolescent \& Adult Literacy, 59(1), 51-61. https://doi.org/10.1002/jaal.426

Kirillov, A. V., Vinichenko, M. V., Melnichuk, A. V., Melnichuk, Y. A., \& Vinogradova, M. V. (2016). Improvement in the learning environment through gamification of the educational process. International Electronic Journal of Mathematics Education, 11(7), 2071-2085.

Klopfer, E. (2008). Augmented learning: Research and design of mobile educational games. Cambridge, Mass: MIT Press. https://doi.org/10.7551/mitpress/9780262113151.001.0001

Lavoue, E., Monterrat, B., Desmarais, M., \& George, S. (2018). Adaptive gamification for 
learning environments. IEEE Transactions on Learning Technologies, 1(1), 1-13. https://doi.org/10.1109/TLT.2018.2823710

Lin, C. J., Hwang, G. J., Fu, Q. K., \& Chen, J. F. (2018). A flipped contextual game-based learning approach to enhancing EFL students' English business writing performance and reflective behaviors. Journal of Educational Technology \& Society, 21(3), 117-131.

McGregor, K. K., Marshall, B. A., Julian, S. K., \& Oleson, J. (2019). Learning While Playing: A Randomized Trial of Serious Games as a Tool for Word Mastery. Language, Speech, and Hearing Services in Schools, 50(4), 596-608. https://doi.org/10.1044/2019_LSHSS-VOIA-180121

Ott, M., \& Tavella, M. (2009). A contribution to the understanding of what makes young students genuinely engaged in computer-based learning tasks. Procedia-Social and Behavioral Sciences, 1(1), 184-188. https://doi.org/10.1016/j.sbspro.2009.01.034

Sarigoz, O. (2019). Augmented Reality, Virtual Reality and Digital Games: A Research on Teacher Candidates. Educational Policy Analysis and Strategic Research, 14(3), 41-63. https://doi.org/10.29329/epasr.2019.208.3

Tan, D. A. L., Lee, B. C., Ganapathy, M., \& Kasuma, S. A. A. (2019). Language Learning in the 21st Century: Malaysian ESL Students' Perceptions of Kahoot. International Journal of Virtual and Personal Learning Environments (IJVPLE), 9(2), 55-71. https://doi.org/10.4018/IJVPLE.2019070104

Tan, D. A. L., Lee, B. C., Ganapathy, M., \& Kasuma, S. A. A. (2019). Language Learning in the 21st Century: Malaysian ESL Students' Perceptions of Kahoot. International Journal of Virtual and Personal Learning Environments (IJVPLE), 9(2), 55-71. https://doi.org/10.4018/IJVPLE.2019070104

Vahdat, S., \& Behbahani, A. R. (2013). The effect of video games on Iranian EFL learners' vocabulary learning. Reading, 13(1), 61-71.

Yolageldili, G., \& Arikan, A. (2011). Effectiveness of using games in teaching grammar to young learners. Online Submission, 10(1), 219-229.

Yukselturk, E., Altıok, S., \& Başer, Z. (2018). Using game-based learning with kinect technology in foreign language education course. Journal of Educational Technology \& Society, 21(3), 159-173. 